\title{
Risk Aversion and Timber Harvest Strategies: A Case Study of Nonindustrial Private Forest Management in Louisiana
}

\author{
Hua Wang ${ }^{1}$ (D) Naveen Adusumilli ${ }^{1}$ (D) $\cdot$ Michael Blazier $^{2} \cdot$ Santosh Pathak $^{3}$ (D)
}

Accepted: 8 December 2021 / Published online: 8 January 2022

(c) The Author(s) 2021

\begin{abstract}
Forest owners face many challenges regarding forest management due to the long period from planting to harvest. Along with the economic and environmental factors that influence management actions, the owners' attitude to risk plays a crucial role in forest management decisions. This study shows that understanding the effects of the owner's risk preference for management actions is an important step to form an effective forest policy. The objectives of the study are to (1) assess the economic advantage of forest management alternatives over a range of risk aversion coefficients and (2) determine the financial incentive (risk premium) corresponding to a forest owners' risk attitude. We implemented the stochastic efficiency with respect to a function framework to evaluate a set of fertilization, herbicide, and thinning management alternatives at mid-rotation loblolly pine plantations in Louisiana. Results from this study indicate that forest owner's risk preference affects their decision to select management actions. Financial incentives are substantially different for specific management alternatives between risk-neutral and risk-averse forest owners. The results can guide forest policy development where agencies can modify financial assistance programs to improve the adoption of management actions.
\end{abstract}

Keywords Forest management $\cdot$ Loblolly pine $\cdot$ Certainty equivalent $\cdot$ Risk premium $\cdot$ Stochastic

\section{Introduction}

The US south is often known as the 'wood basket' due to extensive forest land (>93.9 million hectares) and supplying 16\% of the global forest products (Henderson et al. 2015). Forestry and the forest products industry are essential components of the southern regional economy generating around 1.1 million jobs and \$251 billion of economic output (Henderson et al. 2015). Loblolly pine (Pinus taeda L.) is

Naveen Adusumilli

nadusumilli@agcenter.lsu.edu

Extended author information available on the last page of the article 
one of the many great native tree species and the most common commercial pine species planted on more than 13 million hectares in much of the southeastern United States (Hugget et al. 2013; Schultz 1997). Oswalt et al. (2019) reported that loblolly and shortleaf pines account for $73 \%$ and $25 \%$ of the total net volume of softwood growing stock on timberland in the South and the United States in 2017, respectively. Loblolly pine is partially or fully harvested every 15 to 40 years for various products such as pulpwood, chip-n-saw, paneling, and structural lumber. It is the primary forest product and the most economically important tree species in the region (Oswalt et al. 2019; Schultz 1997). Therefore, the management of loblolly forests for their survival and growth has a substantial economic motive.

In addition, climate change and changing economic conditions continue to impact the forest. At the same time, demand for timber and other wood-related products is expected to increase in response to growing housing markets. Thus, forest management strategies need to be evaluated continuously to overcome some of these risks and reap higher benefits from forest products. Furthermore, private forest owners, including families, individuals, corporations, and other private entities, own around $86 \%$ of the southern US's forest area (Butler and Wear 2013). Private forest owners involved in plantation forestry may be more sensitive to adequate economic incentives (Khanal et al. 2019). Similarly, understanding different forest management options incorporating risks is essential in aligning forest management strategy and expected return from forest plantation. Common forest management strategies include a combination of with-without fertilization and herbicide near the time of thinning treatments at mid-rotation. Hence, it is crucial to understand the influence of fertilization and weed control timing relative to thinning on forest management (Blazier et al. 2015). Moreover, forest management decisions often involve a longtime horizon, and forest owners face risk and uncertainty about eventual production and market conditions (Lien et al. 2007). Therefore, understanding management alternatives and considering forest owner's risk preferences would enhance productivity by appropriately timing management actions and providing additional environmental amenities.

Our objective is to investigate the optimal management practice over a range of risk preferences and determine the forest owner's incentive (risk premium), given their risk attitude. To this end, we focus on private forest owners considering production and market risks, given their relative importance in forest management. This study provides experimental evidence from a long-run experiment about forest management alternatives on yield and net returns. This study also applies the stochastic efficiency with respect to function (SERF) framework to stochastically evaluate a set of fertilization, herbicide, and thinning options in mid-rotation loblolly pine plantations to maximize economic profitability.

\section{Literature Review}

Studies have shown that normal forest management activities such as thinning, fertilization, and weed-control increase site quality and plantation productivity (Blazier et al. 2015; Fox et al. 2007a, b). Since soil fertility is generally lower in pine 
plantations throughout the southern US, thus, fertilization and thinning practices can significantly increase loblolly pine production (Allen et al. 2005; Coyle et al. 2016; Kline and Coleman 2010; Martin and Jokela 2004). Studies have also shown that multiple herbicide and fertilizer applications with proper planting density can improve productivity in loblolly pine plantations (Ferreira et al. 2020; Jokela et al. 2004, 2010).

Considering the uncertainty of forest market price, Brazee and Mendelsohn (1988) applied an asset sale model to explore how harvest strategies ought to adjust to uncertain future timber prices. The authors pointed out that the optimal reservation price is different for each age class, and forest owners should harvest that age class if the current price is above the reservation price. More recently, Brazee and Dwivedi (2015) presented a multiple products optimal rotation model to analyze the impact of shifts in prices for product classes. Results from this study suggested that the optimal rotation age decreases with the increase of sawtimber price but inversely with pulpwood and chip-n-saw prices. By incorporating hazard risk valuation into forest management, Hanewinkel et al. (2011) offered a comprehensive literature review on risk analysis and modeling. The authors evaluated the economic aspects of risk analysis and discussed the Monte Carlo simulation application for incorporating risk into forest management decisions. Focusing on climate change, Yousefpour et al. (2012) provided an overview of optimal decision-making strategies involving risks and uncertainty. They explained the possible use of these methods in forestry management. Using a bioeconomic model, Adams et al. (2020) evaluated potential economic damages to southern pine forests from hypothetical invasive species (Asian bark or ambrosia beetle). The authors indicated that the risk mitigation policy could reduce the economic damage by more than a half. By incorporating the risk of wildfires, Susaeta et al. (2016) applied a generalized Reed model on optimal management of slash pine in the southern United States. The authors found that the future risk of wildfire losses would lengthen the current optimal harvest age. They suggest that it is essential to reduce wildfire risk using incentives for forest landowners to undertake intermediate wildfire treatments.

Moreover, Susaeta and Gong (2019) employ a reservation price model to estimate the joint impacts of natural disturbance and stumpage price uncertainty on the optimal harvesting decision for even-aged forest stands. The authors suggested that forest owners should consider the wildfire risk and market price simultaneously when determining the optimal harvesting decision. In addition to the natural disturbance and market uncertainties, the uncertainty regarding forest owner's risk preferences can exacerbate the evaluation of forest management alternatives for better decisionmaking. Regarding multiple-use forest management decisions, Buongiorno et al. (2017) found that financial risk aversion reduced expected net returns and production and led to shorter cutting cycles compared with risk neutrality or risk-seeking based on the risk-sensitive Markov decision process model using the variance and the certainty equivalent of the financial or ecological criteria.

Forest owner's risk preferences significantly impact forest management (Andersson and Gong 2010; Brunette et al. 2017; Couture et al. 2016). Forestry specialists have used the degree of risk aversion for measuring forest owner's willingness to avoid economic risk in forest management (Andersson and Gong 2010; Armstrong 
2004; Jacobsen and Helles 2006; Yousefpour et al. 2012). Forest economists typically assume that forest owners are risk-neutral or risk-averse when evaluating a forest management decision with uncertainty (Andersson 2012). However, risk preferences depend on the amount of money at stake (Lönnstedt and Svensson 2000) and the owner's willingness to take the financial risk (Andersson and Gong 2010). Forest owner's preferences for management strategies can change if incentive payments cover some economic loss (Adusumilli et al. 2020). Furthermore, property characteristics also affect the owner's attitudes towards risk (Andersson 2012). Thus, accounting for forest owner's risk preferences is essential for evaluating forest management alternatives and identifying the economic incentive to shift among management options.

A rational forest owner would choose a management action that is most beneficial and cost-effective (Austin et al. 2020; Lintunen 2011). Consequently, a change in either the benefit or cost of potential decisions can change the owner's behavior (Leskinen and Kangas 2001; Taylor and Fortson 1992). A management alternative not preferred on the grounds of cost-effectiveness can become a part of the portfolio of practices if one can appropriately estimate the difference in costs of the current practice and the new practice. However, one needs to also account for the impact of the practice on profitability and the forest owner's risk tolerance (Kant and Alavalapati 2014; Gong and Löfgren 2003; Uusivuori 2002). Some methods might decrease returns in the initial years before becoming profitable later. It is worth noting that forest owners balance tradeoffs between risk and profitability depending on their risk attitudes (Andersson and Gong 2010; Brunette et al. 2017). Our research addresses this concern by comparing the distribution of net benefits from a set of management alternatives for mid-rotation loblolly pine plantations and estimating how preference for management alternatives changes with risk attitudes.

A few papers evaluated the impact of owner's risk aversion on various forest management decisions using stochastic efficiency techniques (Caulfield 1988; Gong 1998; Lien et al. 2007). Caulfield (1988) applied stochastic dominance with respect to a function approach to incorporate risk-aversion into forest rotation management. Based on the deterministic land expectation value, mean-variance rule, and meancoefficient of variation rule, the author demonstrates how to apply the technique in practice to identify more than one risk-efficient rotation alternatives. Considering the final harvest decision in even-aged stand management with stochastic stumpage prices, Gong (1998) used the same technique to evaluate a set of efficient adaptive harvest policies for risk-averse forest owners. Results from this study suggested that risk-averse forest owners prefer the optimal adaptive harvest strategy to the optimal rotation age and that incorporation of risk-aversion may lead to a low reservation price.

The limitation of applying the stochastic dominance technique is that this method is sequentially to select utility functions and use only pairwise comparisons between alternatives to determine whether one dominates the other (Hardaker et al. 2004). Nevertheless, Lien et al. (2007) employed a different stochastic efficiency approach - that is, stochastic efficiency with respect to a function, which is the method that used to rank a set of risky alternatives in terms of certainty equivalents-to estimate optimal tree replanting decisions on an area of recently harvested 
forest land. The authors found that the risk aversion of forest owners affected both the optimal tree replacement strategy and the reinvestment decision. They also suggested that policymakers consider the level of risk aversion when designing a forest policy to foster forest investment. Unlike the stochastic dominance method, the SERF method provides a framework for estimating the level of incentives through certainty equivalent $(\mathrm{CE})$ values between two or more alternatives. The method is an improvement over previous stochastic methods as it allows for simultaneous evaluation of management alternatives and provides a pairwise comparison across those management activities.

Furthermore, the SERF identifies and orders efficient alternatives at each risk aversion level. Uncertainty in the future affects feasible forest management strategies and forest owner's preferences among different options. Both effects should be recognized simultaneously when making a management decision with uncertainty. The present study extends the previous literature by incorporating the risk nature of an individual in adopting a management alternative and is the first study to apply the SERF method in loblolly pine forests management. The results provide a range of certainty equivalent values, considering the heterogeneity of individual decisionmaking for adopting management actions that improve productivity and reduce economic loss.

\section{Methods}

\section{Experimental Design and Data}

The study from which yield data were collected was described by Blazier and Scott (2006) and Blazier et al. (2015); key information about the study will be described here. The site was located in Jackson parish in North Central Louisiana, near Dodson $\left(32.0727^{\circ} \mathrm{N}, 92.6697^{\circ} \mathrm{W}\right)$ and comprised 12 plots (Fig. 1). Each plot had dimensions of 45 by $45 \mathrm{~m}$, with a total area of 0.2 hectares. The soil in this location is a moderately well-drained, fine-loamy texted soil mapped as a US Department of Agriculture Natural Resource Conservation Service Bowie series (USDA-NRCS 2020). Loblolly pine seedlings were planted in 1990. Before planting, the site was prepared via drum chopper and prescribed burning.

The site was part of a study on improving the timing of mid-rotation silvicultural treatments for loblolly pine plantations. The purpose of the study was to determine the optimum time relative to thinning for conducting herbicide release and/or fertilization treatments relative to thinning. Landowners in regions with abundant sawtimber markets have incentives to increase the development rate of sawtimber, with sawtimber production motivation generally increasing with increasing land area owned among non-industrial private forest landowners. These utilitarian non-industrial private forest landowners often work with forestry consultants, who guide management of their lands similar to those of corporate forest landowners. Mid-rotation herbicide release treatments also enhance herbaceous vegetation by reducing the reestablishment of a mid-story after thinning. This increase in herbaceous vegetation 


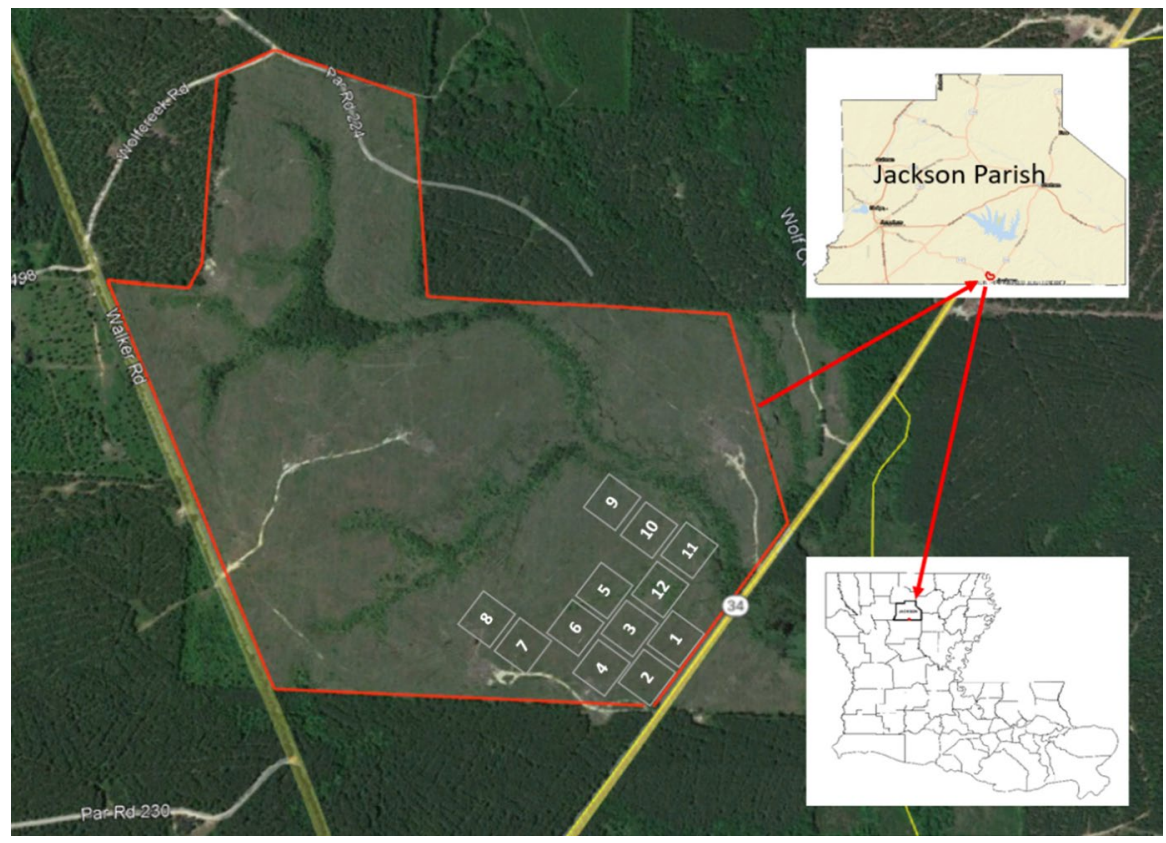

Fig. 1 Study site location and plot configuration. Inserts denote the parish and state in which the study was located

has wildlife benefits as browse and cover vegetation, so landowners interested in wildlife enhancement sometimes conduct release treatments.

To better understand timing relative to thinning, a range of timing treatments were conducted. Herbicide and fertilizer are typically applied in the year of thinning, so this timing was conducted as a 'business-as-usual' practice. Herbicide and fertilizer were also applied one-year post-thining to determine whether postponing these treatments would better align with tree nutrient demands. Thinning is associated with a greater release of nutrients as the soil temperature is increased with larger canopy openings, and logging slash is left to decompose. Our post-thining timing was done to determine whether waiting until this thinning-induced nutrient release would lead to better growth responses to herbicide and fertilization. Further details about the site and study rationale are provided in Blazier and Scott (2006) and Blazier et al. (2015). In this study, we tested for the effects of two treatments-fertilization and herbicide application. Between 2004 and 2006, fertilizer and herbicide timing treatments were applied. Fertilization treatments consisted of: (1) No fertilization (NF), (2) Fertilization on the year of thinning (FYOT), and (3) Fertilization one year after thinning (FYAT). Similarly, herbicide treatments consisted of: (1) No herbicide (NH), (2) Herbicide on the year of thinning (HYOT), and (3) Herbicide one year after thinning (HYAT).

Treatments were applied as a randomized complete block design with the slope as blocking factor to 0.1 ha plots; treatments were replicated three times. Fertilizer treatment consisted of a mixture of urea and diammonium phosphate supplying 
$0.135 \mathrm{t} \mathrm{N}$ and $0.013 \mathrm{t} \mathrm{P} \mathrm{ha}^{-1}$, respectively. These fertilization rates were selected because they were $75 \%$ of common mid-rotation loblolly pine fertilization rates at the time of study establishment (Fox et al. 2007a). The slightly lower-than-operational rate was used in this study to elucidate the combination of stand conditions (thinned versus non-thinned, vegetation suppression versus non-suppression, the timing of application relative to thinning) that would be amenable to a lower-thanoperational fertilization rate while still promoting a stand growth increase. Given price reductions in forest products and associated reductions in fertilized forest acreage since the inception of this study (Albaugh et al. 2019), this facet of the rate selected could be helpful in identifying loblolly pine management combinations that still foster fertilization as a viable management option. Furthermore, the fertilization rates used in this study are within the range of the most common operational rates for the southeastern United States reported by Albaugh et al. (2019) for both N and $\mathrm{P}$, with the proportion of land area receiving rates in this range increasing in the more recent years reported as research revealed efficacy of lower rates, forest product values declined, and fertilizer prices increased.

Herbicide was applied as a directed spray of a $20 \%$ solution of triclopyr for hardwood tree and shrub suppression. Similarly, a directed spray of 5\% solution of glyphosate was applied for controlling herbaceous vegetation and hardwood sprouts. The site was operationally thinned to a residual density of 494 trees ha $^{-1}$ in October 2004 (stand age 14 years). Fertilizer and herbicide treatments were applied in April 2004, April 2005, and April 2006 for year-before, year-of, and year-after thinning timings, respectively.

Tree dimensions such as height and diameter at breast height were used to derive yield information, which was measured immediately prior to thinning and in September 2018, immediately before the site's operational harvest at stand age 28 years. The regression model of Bullock and Burkhart (2003) was used for predicting total green stem weight from height and diameter at breast height to derive every harvested tree's weight. These measurements were then summed for each plot and scaled to the per-hectare level. Yields were divided into pulpwood, chip-n-saw, and sawtimber products based on diameter at breast height at the time of thinning and harvest. Pulpwood, chip-n-saw, and sawtimber yields were derived by summing weights of trees with diameter at breast height between 13 to $20 \mathrm{~cm}, 20$ to $33 \mathrm{~cm}$, and $>33 \mathrm{~cm}$, respectively (Blazier and Dunn 2008).

\section{Net Returns Simulation}

Harvest data of loblolly pine, including pulpwood, chip-n-saw, and sawtimber under different treatments, were collected at the study site in September 2018, with measurements coinciding with the stand's operational harvesting in which the study was located. The timber price data was obtained from the Louisiana Timber Market Report (Tanger 2019). The average prices were $\$ 25.35, \$ 18.74$, and $\$ 8.82 \mathrm{t}^{-1}$ for pine sawtimber, pine chip-n-saw, and pine pulpwood products. The 2008 Farm Bill includes a number of forestry cost-share and assistance programs for landowners to help them improve soil and water quality on their land through the USDA 
Table 1 Louisiana payment schedules for forest management plan under environmental quality incentives program, the fiscal year 2019. Source USDA Natural Resource Conservation Service Environmental Quality Incentives program-Louisiana payment schedules for 2019 fiscal year

\begin{tabular}{ll}
\hline Forest land size & $\begin{array}{l}\text { Financial } \\
\text { assistance } \\
\text { payment }\end{array}$ \\
\hline Forest management plan less than or equal to 8 hectares & $\$ 1078$ \\
Forest management plan 9 to 40 hectares & $\$ 1362$ \\
Forest management plan 41 to 101 hectares & $\$ 2440$ \\
Forest management plan 102 to 202 hectares & $\$ 3518$ \\
Forest management plan 203 to 405 hectares & $\$ 4086$ \\
Forest management plan greater than 405 hectares & $\$ 5107$ \\
\hline
\end{tabular}

Natural Resources Conservation Service (NRCS) and the USDA Farm Services Agency (Cowan and Johnson 2008). Thus, government incentives were considered a potential source of additional revenue for those willing to adopt a forest management plan through participation in the Environmental Quality Incentives Program. ${ }^{1}$ Forest owners who adopt a forest management plan in Louisiana are eligible for a lump sum conservation payment ranging from $\$ 1078$ to $\$ 5107$ based on the enrolled hectares (Table 1). Results from the 2017-2018 National Woodland Owner Survey (Bulter et al. 2020) indicate that most family forest owners in the State hold 9 to 40 hectares. Thus, we assume that the total of $\$ 1362$ represents the average cost-share payment in Louisiana and this value is used in the net returns simulation.

The total cost for timber production was based on the 2018 Cost \& Trends of Southern Forestry Practice report (Maggard and Barlow 2019). The total cost for this site included site preparation and mid-rotation treatment costs, and the estimated total expenses were $\$ 1,156 \mathrm{ha}^{-1}$. Net returns were then simulated per hectare using the Monte Carlo method for fertilizer and herbicide treatments under different harvest strategies of loblolly pine based on the following function:

$$
N R_{i j}=P_{i} Y_{i j}+I_{i j}-T C
$$

\footnotetext{
${ }^{1}$ Natural Resources Conservation Service provides financial assistance to producers through Environmental Quality Incentives Program for selected conservation practice (including forest management) to address natural resource concerns and deliver environmental benefits. The Environmental Quality Incentives Program is one of the main cost-share programs for private forestland owners to implement conservation and management practice(s) for improving health and productivity of private forests.
} 
where $N R_{i j}$. represents the net returns measured in $\$ \mathrm{ha}^{-1}$ for each harvest products $(i=1,2,3)$ under different treatments $(j=1, \ldots, 6)^{2} ; P_{i}$ is the market timber price $\left(\$ \mathrm{t}^{-1}\right) ; Y_{i j}$ stands for the average yield measured in $\mathrm{t} \mathrm{ha}^{-1} ; I_{i j}$ represents the forest management incentives sponsored by the Environmental Quality Incentives Program; and $T C$ is the total costs per hectare for major forestry practices. $T C$ includes costs incurred in mechanical site preparation $\left(\$ 450.41 \mathrm{ha}^{-1}\right)$, prescribed burning $\left(\$ 168.03 \mathrm{ha}^{-1}\right)$, tree planting by hand $\left(\$ 82.43 \mathrm{ha}^{-1}\right)$, mid-rotation chemical (herbicide) application $\left(\$ 163.63 \mathrm{ha}^{-1}\right)$, fertilizer application $\left(\$ 261.68 \mathrm{ha}^{-1}\right)$, and timber cruising ( $\$ 30.32 \mathrm{ha}^{-1}$ ). All monetary values are adjusted to the 2019 dollar.

Yield, income, and net returns depend on harvest alternatives and the timings of fertilizer and herbicide application by the forest owner. Analysis of variance was used to compare the averages of yield, income, and net returns for each of the treatments using the SAS 9.4. Pairwise comparisons were made between the mean yield, income, and net returns for FYOT-NH treatment and alternatives using Fisher's least significant difference test at the $5 \%$ significance level.

\section{Stochastic Efficiency with Respect to a Function}

Risk analysis was conducted using stochastic efficiency with respect to a function method (SERF). The SERF method uses utility-efficient alternatives for ranges of risk attitudes and orders a set of risky alternatives in terms of certainty equivalent (CE) over a defined range (Hardaker et al. 2004). The CE is the sure amount of money with the same utility as the expected utility of a risky alternative (Keeney and Raiffa 1976). To calculate the CE's, a utility function of a forest farmer, $U(w)$, is used with the performance criterion wealth (w). Assuming $f_{1}(w), f_{2}(w), \ldots, f_{n}(w)$ are the probability density functions describing $\mathrm{n}$ risky alternatives outcome, and the corresponding cumulative distribution functions are represented by $F_{1}(w), F_{2}(w), \ldots, F_{n}(w)$. Since the shape of the utility function reflects owner's attitude towards risk. An owner's exact risk aversion is unspecified and is unknown (Schumann et al. 2004). According to the subjective expected utility hypothesis (Anderson et al. 1977), the utility of any risky alternative is the expected value. Thus, the function for a specified utility can be calculated depending on the degree of risk aversion $(r(w))$ and the stochastic variable of wealth, which can be defined as: $U(w, r(w))=\int U(w, r(w)) f(w) \mathrm{d} w=\int U(w, r(w)) \mathrm{d} F(w)$. The utility function, $U(\bullet)$, is estimated for selected values of $r(w)$ between the lower and upper bounds $r_{l}(w)$ and $r_{u}(w)$ (Hardaker et al. 2004).

The certainty equivalents can be determined by taking the reverse of the utility function and is specified as the amount of certain payoff with the utility as the

\footnotetext{
${ }^{2}$ Harvest strategy consisted of thinning at stand age of 14 years and clearcutting at stand age of 28 years for products such as pulpwood, chip-n-saw, and sawtimber. In this study, we have a total of eight treatment combinations, i.e., (1) no fertilization, no herbicide; (2) no fertilization, herbicide the year of thinning; (3) fertilization the year before thinning, no herbicide; (4) fertilization the year before thinning, herbicide the year before thinning; (5) fertilization the year of thinning, no herbicide; (6) fertilization the year of thinning, herbicide the year of thinning; (7) fertilization one year after thinning, no herbicide; (8) fertilization one year after thinning, herbicide one year after thinning.
} 
expected utility of the risky alternative (Williams et al. 2012). The risk premium could then be calculated by subtracting the certainty equivalent of the less preferred option from the preferred strategy at a specific risk aversion level and is the amount that a decision must be paid to accept an inferior alternative. The SERF method provides a framework to estimate the certainty equivalent and utilityweighted risk premiums between alternatives and provide a cardinal measure to compare the payoffs between risky investments (Hardaker et al. 2004).

\section{Certainty Equivalent}

Andersson and Gong (2010) pointed out that many forest owners are not riskneutral, and the degree of risk aversion plays a crucial role in making timber harvest decisions. Given this, the SERF framework can be employed using utilityefficient alternatives for ranges of risk attitudes. This method considers the full range of decision-maker preferences and is regarded as a more efficient technique to rank production alternatives (Hardaker et al. 2004). The simulated net returns data for each harvest strategy and treatment are used as the basis for the SERF analysis to rank forest management alternatives. The SERF method orders the alternatives in terms of certainty equivalents (CEs) over a range of risk preferences (Hardaker et al. 2004). The CEs represent the value of treatment alternatives, which is the sure sum with the same utility as the prospect's expected utility. CEs can be calculated by taking the inverse of the utility function given by:

$$
C E(w, r(w))=U^{-1}(w, r(w))
$$

where $r(w)$ represents the absolute, relative, or partial risk aversion coefficient with respect to wealth $(w)$ and it depends on the utility function specified. The CE is expressed in $\$ \mathrm{ha}^{-1}$ and the estimated CE is less than the expected monetary value for a rational decision-maker who is risk-averse.

Schumann et al. (2004) noted that choosing utility functions with the assumption of concavity in the range of risk aversion and weighting them to create a composite ranking can be useful to analyze decision-maker's choices under quasirisk aversion conditions. In this study, a negative exponential utility function is used in conformity with the hypothesis that forest owners prefer less risk to more, given the same expected return. The negative exponential function indicates that forest owners have a constant absolute risk aversion and view a risky strategy for a specific risk aversion level without regard for their wealth level (Babcock et al. 1993; Pendell et al. 2007). The negative exponential function can be used as a reasonable approximation of risk-averting behavior (Schumann et al. 2004; Williams et al. 2009), and the utility function is given by (Hardaker et al. 2004):

$$
U(w)=-\exp \left(-r_{a}(w) w\right)
$$

Thus, the estimated CE can be mathematically represented as: 


$$
C E\left(w, r_{a}(w)\right)=\ln \left(\frac{1}{n} \sum_{i}^{n} \exp \left(-r_{a}(w) w_{i}\right)\right)^{\frac{1}{r_{a}(w)}}
$$

where $r_{a}(w)$ is the absolute risk aversion coefficient with respect to wealth $(w) ; n$ stands for the random sample size; $w$ represents treatment alternatives with $i$ possible outcomes.

Certainty equivalent graphs can be used to show the ordinal rankings of forest management practices across a specified range of absolute risk aversion coefficient values. Graphical representation of SERF results facilitates ordinal rankings of management practices for decision-makers with different risk attitudes. The certainty equivalent graphs also provide a cardinal measure of decision-maker's preferences among risky alternatives at each risk aversion level by interpreting differences between CE values as risk premiums (Hardaker et al. 2004).

\section{Absolute Risk Aversion Coefficient}

Hardaker et al. (2004) outlined the methodology for analyzing risky alternatives. CE values over a range of absolute risk aversion coefficients (ARACs) $r_{a}(w)$ are calculated. The coefficient of absolute risk aversion can be applied to consequences measured in terms of wealth or income (Anderson and Hardaker 2003). ARAC represents a decision-maker's degree of risk aversion. If $\mathrm{ARAC}>0, \mathrm{ARAC}=0$, or $\mathrm{ARAC}<0$, the decision-makers are classified as risk-averse, risk-neutral, or risk preferring, respectively. ARAC values were calculated using the following formula proposed by Hardaker et al. (2004):

$$
A R A C_{w}=\frac{r_{r}(w)}{w}
$$

where $r_{r}(w)$ is the relative risk aversion coefficient with respect to wealth $(\mathrm{w}) . r_{r}(w)$ was set to 0 (for risk-neutral forest owner) to approximately 4 (very risk-averse forest owner) as proposed by Anderson and Dillon (1992). In this study, wealth (w) was calculated based on the respective mean net returns from loblolly pine products under different treatments. The ARAC values ranging from 0 to 0.0018 correspond to the relative risk aversion coefficient of 0 to 4 among the harvest strategies. Thus, the ARAC values in the range of 0 to 0.0018 were used in the SERF analysis to calculate $\mathrm{CE}$ values for each harvest strategy under different treatment alternatives.

\section{Risk Premium}

The estimated CE is usually less than the expected money value for a rational decision-maker who is risk-averse. The difference between the expected money value and the CE is the risk premium (Hardaker et al. 2004). According to Richardson et al. (2006), we estimated the utility-weighted risk premiums for management practices by subtracting the $\mathrm{CE}$ values from the corresponding status-quo practice at 
Table 2 Yield and yield contribution of each product under various treatments for loblolly pine plantation

\begin{tabular}{|c|c|c|c|c|}
\hline \multirow[t]{2}{*}{ Treatments } & \multirow{2}{*}{$\begin{array}{l}\text { Mean } \\
\text { yield (t } \\
\left.\mathrm{ha}^{-1}\right)\end{array}$} & \multicolumn{3}{|c|}{ Yield contribution (\%) } \\
\hline & & Pulpwood & Chip-n-saw & Sawtimber \\
\hline NF-NH & $247^{\mathrm{a}}$ & 27.1 & 45.4 & 27.5 \\
\hline NF-HYOT & $253^{\mathrm{a}}$ & 25.9 & 40.1 & 34.0 \\
\hline FYOT-NH & $283^{\mathrm{a}}$ & 28.5 & 42.4 & 29.1 \\
\hline FYOT-HYOT & $236^{\mathrm{a}}$ & 25.1 & 43.7 & 31.1 \\
\hline FYAT-NH & $243^{\mathrm{a}}$ & 28.7 & 50.5 & 20.9 \\
\hline FYAT-HYAT & $249^{\mathrm{a}}$ & 27.9 & 44.3 & 27.8 \\
\hline
\end{tabular}

Yields are summed from thinning yields from stand age 14 and complete harvest at stand age 28; Mean yield of treatments with different superscripts are significantly different at $p<0.05$ with respect to Fisher's least significant difference post hoc analysis

Table 3 Mean income, income contribution of each product, and mean net return under various treatments for loblolly pine plantation

\begin{tabular}{llllll}
\hline Treatments & $\begin{array}{l}\text { Mean income } \\
\left(\$ \mathrm{ha}^{-1}\right)\end{array}$ & \multicolumn{2}{l}{ Income contribution $(\%)$} & $\begin{array}{l}\text { Mean net } \\
\text { return }(\$ \\
\left.\text { ha }^{-1}\right)\end{array}$ \\
\cline { 3 - 5 } & Pulpwood & Chip-n-saw & Sawtimber & $3,732^{\mathrm{c}}$ \\
NF-NH & $4,448^{\mathrm{d}}$ & 13.3 & 47.6 & 39.0 & $5,488^{\mathrm{ab}}$ \\
NF-HYOT & $6,367^{\mathrm{abc}}$ & 12.4 & 40.8 & 46.8 & $5,788^{\mathrm{ab}}$ \\
FYOT-NH & $6,766^{\mathrm{abc}}$ & 14.1 & 44.6 & 41.4 & $6,562^{\mathrm{a}}$ \\
FYOT-HYOT & $7,704^{\mathrm{a}}$ & 12.1 & 44.8 & 43.1 & $4,926^{\mathrm{bc}}$ \\
FYAT-NH & $5,903^{\mathrm{bcd}}$ & 14.6 & 54.8 & 30.6 & $6,695^{\mathrm{a}}$ \\
FYAT-HYAT & $7,836^{\mathrm{a}}$ & 13.8 & 46.6 & 39.6 &
\end{tabular}

Yields are summed from thinning yields from stand age 14 and complete harvest at stand age 28; Values of mean income and net returns with differing superscripts are significantly different at $p<0.05$ with respect toFisher's LSD post hoc analysis.

given ARAC values. Risk premiums determine the confidence of a decision-maker in a preferred alternative and is estimated using the following formula:

$$
R P_{A, B, r(w)}=C E_{A, r(w)}-C E_{B, r(w)}
$$

where $C E_{A, r(w)}$ and $C E_{B, r(w)}$ are the CEs of alternatives $\mathrm{A}$ and $\mathrm{B}$, respectively, at a given risk aversion level of $r(w)$, and $R P_{A, B, r(w)}$ is the resulting utility-weighted risk premium (RP). The risk premium yields a measure of preference for one alternative over the other at a given risk aversion level. The $R P_{A, B, r(w)}$ is the minimum amount that a decision-maker would receive to switch from alternative $\mathrm{A}$ to alternative $\mathrm{B}$ under a specific risk-aversion coefficient (Hardaker et al. 2004). 
Fig. 2 SERF results for fertilizer and herbicide management alternatives using a negative exponential utility function and absolute risk aversion range from 0 to 0.0018

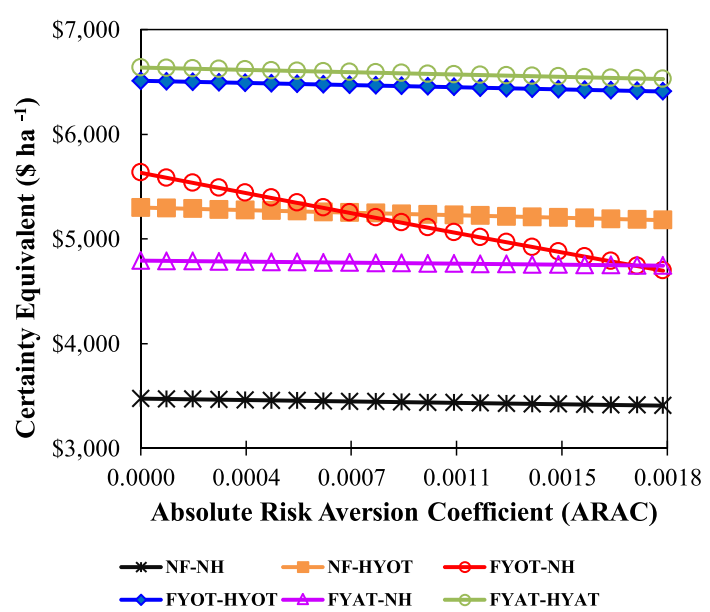

\section{Results and Discussion}

The results showed that the mean yields of loblolly pine were statistically similar among treatment combinations (Table 2), but the proportions of products and the income differed (Table 3). The mean yield ranged from 243 to $283 \mathrm{t} \mathrm{ha}^{-1}$ among different fertilizer and herbicide management alternatives. The yield of loblolly pine under various treatment alternatives is presented in Table 2. The least significant difference tests found no significant differences between NF-NH and alternative treatments for mean yield. ${ }^{3}$ The chip-n-saw product contributes almost half of the mean yield, while sawtimber and pulpwood products contribute equally about $27 \%$ to loblolly pine's mean yield.

NF-NH: $\quad$ No fertilization; No herbicide

NF-HYOT: No fertilization; Herbicide the year of thinning

FYOT-NF: $\quad$ Fertilization the year of thinning; No herbicide

FYOT-HYOT: Fertilization the year of thinning; Herbicide the year of thinning

FYAT-NH: Fertilization one year after thinning; No herbicide

FYAT- HYAT: Fertilization one year after thinning; Herbicide one year after thinning

Mean income among treatments ranged from $\$ 4448$ to $\$ 7836 \mathrm{ha}^{-1}$ and net returns ranged from $\$ 3732$ to $\$ 6695 \mathrm{ha}^{-1}$ (Table 3). All treatments had higher mean income and mean net returns than the NF-NH treatment. The FYAT-HYAT and

\footnotetext{
3 The standard is to use NF-NH as a control; however, this practice is particularly not common among forest owners. The most common practice in private forestland is NF-HYOT. Therefore, we use NFHYOT as a reference management action to compare risk premiums against other management alternatives.
} 
Table 4 Risk premiums (\$ $\mathrm{ha}^{-1}$ ) for treatments with various absolute risk aversion coefficients

\begin{tabular}{llllll}
\hline Treatments & \multicolumn{5}{l}{ Risk aversion level } \\
\cline { 2 - 6 } & 0.0000 & 0.00005 & 0.00010 & 0.0015 & 0.0018 \\
\hline NF-HYOT $^{\dagger}$ & $\$ 0$ & $\$ 0$ & $\$ 0$ & $\$ 0$ & $\$ 0$ \\
FYOT-NH & $\$ 369$ & $\$ 152$ & $(\$ 124)$ & $(\$ 371)$ & $(\$ 581)$ \\
FYOT-HYOT & $\$ 1,043$ & $\$ 1,043$ & $\$ 1,042$ & $\$ 1,040$ & $\$ 1,039$ \\
FYAT-HYAT & $\$ 1,231$ & $\$ 1,227$ & $\$ 1,222$ & $\$ 1,216$ & $\$ 1,211$ \\
\hline
\end{tabular}

${ }^{\dagger}$ Reference management alternative-i.e., management option that we assume the forest owner is currently practicing

FYOT-HYOT treatments had higher mean income and net returns than the FYOTNH, NF-HYOT, and FYAT-NH treatments.

Notes: Yields are summed from thinning yields from stand age 14 and complete harvest at stand age 28; Values of mean income and net returns with differing superscripts are significantly different at $p<0.05$ with respect to Fisher's LSD post hoc analysis.

Figure 2 provides a graphical explanation of how different groups of forest owners might rank management alternatives. ARAC values for risk-averse forest owners vary under each scenario with changes in final wealth. A forest owner's degree of risk aversion substantially influences the $\mathrm{CE}$ for all management strategies under consideration. A higher $\mathrm{CE}$ value for any management alternative, either for a riskneutral or risk-averse forest owner, shows that the forest owner is better off implementing the practice with a higher $\mathrm{CE}$ value than the current practice. The treatment with the lowest CE, on the contrary, can be considered as the least preferred management option.

The results suggest that the $\mathrm{CE}$ values within the fertilizer and herbicide management strategies are significantly different among risk-neutral and risk-averse forest owners. This finding indicates that the timing of fertilization and herbicide application has a significant effect on mean income. Applying fertilizer and herbicide strategies, irrespective of their timing relative to thinning, are considered the least risky alternative as they offer higher net returns. FYAT-HYAT and FYOT-HYOT represent those alternatives. The results show that the most preferred strategy among risk-averse and profit maximizers (risk-neutral) forest owners is FYAT-HYAT, as indicated by higher CE values (green line in Fig. 2) than other management actions. This result may be because the FYAT-HYAT treatment combination resulted in the highest income and net returns while delaying the expenses of fertilization and herbicide relative to other application timings tested.

In loblolly pine plantations, forest managers carry out fertilization and herbicide application in the year of thinning. However, the analysis suggests that it might be economically prudent to delay these treatments by one year. Risk-neutral forest owners would be better off using fertilizer and herbicide management alternatives with a relatively low preference for timing relative to thinning. For risk-averse forest owners, the rankings of treatments are nearly the same except for the FYOT-NH 
treatment combination, which ranks lower than NF-HYOT and FYAT-NH treatments (Fig. 2).

The difference of $\mathrm{CE}$ values between alternatives, termed as risk premiums and measured in $\$ \mathrm{ha}^{-1}$, can provide an estimate of the financial incentive forest owners might or might not need to offset the risk associated with switching from one management practice to another. A forest owner would require an increase in net returns equivalent to the risk premium to change from their current practice. The risk premiums are presented in Table 4. The base scenario for comparison is selected as NF-HYOT. This selection is based on the discussion with forest extension agents and forestry specialists, which indicated that Louisiana forest landowners have the NF-HYOT as the most common practice.

The selection of management alternatives included for risk premium comparison is based on the conservation agencie's goals which would like to see an increase in adoption of those strategies by the forest owners. Therefore, only four management alternatives are compared against the base scenario. The positive risk premium values represent the minimum amount a forest owner would need to shift from their current practice (NF-HYOT) to any other management practice listed in Table 4. In contrast, the negative risk premiums reflect the minimum amount of money the forest owner must be paid to shift to that practice from NF-HYOT. For a risk-neutral owner (profit maximizer), a minimum of $\$ 369 \mathrm{ha}^{-1}$ is needed to shift from NFHYOT to FYOT-NH. This is attributed to the forest owner's preference for weed control in the stand to minimize production losses. For the practice FYOT-NH, among more risk-averse farmers, risk premiums become negative to shift from NFHYOT reflect the current practice has a higher net return. It is not necessary to shift from the base scenario to an inferior scenario. Thus, a risk-averse farmer would not need any incentive (negative amount equates to no incentive required) in this case. However, suppose a forest owner is forced to operate an inferior scenario (a lower net return practice) under a policy. In that case, the forest owner should be paid to accept the alternative management practice.

It is interesting to note that if the choice is limited to selecting either nutrient management or an herbicide management plan, risk-neutral (profit-maximizing) forest owners prefer an herbicide management plan. In contrast, more risk-averse forest owners prefer a fertilizer management plan. A risk-neutral forest owner would need as much as $\$ 1,231 \mathrm{ha}^{-1}$ to adopt both fertilizer and herbicide management plans. As both strategies become available, a higher incentive is expected for delaying fertilizer and herbicide activities by a year after thinning. Although the net returns among the management strategies (year-before, year-of, and year-after thinning) are not significantly different, the difference in premium can be attributed to the time factor involved in delaying the operation and the risk nature of the forest owner, and the confidence in the management strategy. As risk aversion increases among forest owners, these premiums decrease for the most part, albeit in most cases not substantially.

Previous studies showed that the private forest owner's harvesting decision is impacted by risk attitude (Lönnstedt and Svensson 2000; Andersson and Gong 2010; Andersson 2012; Brunette et al. 2017). This research suggests that preference for management actions is influenced by net returns and the forest owner's risk 
nature, which makes these forest owners an attractive target audience for the policymaker. Any new or modified forest policies, including a cost-share incentive policy, will positively or negatively impact a forest owner's cost and net return and influence their risk perception. Farmers adopt a new management practice or enroll in a conservation program depending on their risk perception since risk preference plays a key role in forest management (Hardaker et al. 2004; Zhang and Chang 2018). Thus, forest owner's attitude to risk was an important criterion that policymakers should consider when developing or modifying a forest policy. The risk premiums from this study can be used as a tool for policymaking where financial assistance to forest owners is discussed to promote management actions focusing on herbicide or fertilizer use or both.

\section{Conclusions}

Forest owners face many substantial challenges regarding forest resources management due to the long period from planting to harvest. Therefore, forest owner's risk preference plays a crucial role in forest management. Policymakers are increasingly concerned with understanding the effects of the owner's risk preference for management actions and must decide how to allocate financial incentives optimally. Uncertainty in forest management has been widely acknowledged. Thus, determining the forest owner's response to risk is important to form an effective forest policy. This study attempts to evaluate forest management alternatives, especially fertilization and herbicide application strategies, and rank those alternatives over the range of risk aversion coefficients. The certainty equivalent values facilitate the estimation of risk premiums while the RPs measure the minimum amount forest owners anticipate receiving to change their current practice(s). Differences in risk premiums illustrate important variations that should be accounted for when policymakers decide on the effectiveness of an incentive policy to promote the adoption of management actions.

This study contributes to the literature by modeling loblolly pine forest management under production (yield) and market (price and net returns) risks and ranking forest management alternatives based on the estimated CE values using the SERF framework. This research provides empirical knowledge on forest owner's risk perception and optimal harvest strategy that will help reduce the risk for forest owners. The risk premiums, estimated as the difference in CE values, serve as a reference for evaluating whether the current cost-share incentives will drive expected forest management activities. The findings provide critical managerial insights in forest management planning based on economic and risk criteria. The modeling technique has been used in evaluating conservation choices in crop production enterprises (Wang et al. 2020) but not in loblolly pine management. Moreover, this methodology is easy to adjust for various forest production zones using alternative forest management methods.

Our framework shows how the incorporation of risk parameters changes the optimal returns from forest plantations. Compared to NF-NH, we find that all other treatments result in higher economic benefits for the forest owner. More specifically, forest management practices such as FYAT-HYAT and FYOT-HYOT are 
promising to ensure higher profitability. However, landowners need high incentives $(\sim \$ 1000-1200)$ to shift to these promising practices. Our analysis also indicates that variability associated with yield and related net return makes risk preference a critical consideration in adopting a different harvest strategy. The explicit recognition of uncertainty and subsequent revision of management plans allows farmers to reap more benefits even with the inherent risks associated with weather, market, and individual decision-making on forest production enterprises.

However, some limitations should be noted to assist in the quantification of the results. First, the empirical growth data used to derive the yield distribution were from one of the four study sites (two sites have been destroyed by hurricanes and one by a pesticide drift) in Louisiana. The constraints of the growth data could limit the applicability of the results to the whole southern region and different pine species. Second, the framework is based on the net returns alone to estimate the CE values, which might not tell the whole story since environmental variables and other externalities may influence the system in the long run. The framework also does not consider the difference in externalities for the forest management alternatives evaluated in this analysis. Third, the simulated yield and price are limited to the historical correlation. The results may be sensitive to a change in price, yield, and discount rate. Finally, this study estimates forest management alternatives only based on owner's risk attitudes. For future study, major sources of risk (e.g., wildfire, extreme weather, market risk, and financial risk) should be considered to extend the SERF methodology for forest management analysis. Nevertheless, this analysis provides a crucial starting point that can guide forest management discussions regarding appropriate cost-share assistance by using the SERF framework for incorporating the owner's risk perception in forest management.

\section{Declarations}

Conflicts of interest The authors declare no conflict of interest.

Open Access This article is licensed under a Creative Commons Attribution 4.0 International License, which permits use, sharing, adaptation, distribution and reproduction in any medium or format, as long as you give appropriate credit to the original author(s) and the source, provide a link to the Creative Commons licence, and indicate if changes were made. The images or other third party material in this article are included in the article's Creative Commons licence, unless indicated otherwise in a credit line to the material. If material is not included in the article's Creative Commons licence and your intended use is not permitted by statutory regulation or exceeds the permitted use, you will need to obtain permission directly from the copyright holder. To view a copy of this licence, visit http://creativecommons.org/licen ses/by/4.0/.

\section{References}

Adams DC, Susaeta A, Soto JR, Rossi F, de Grammont PC, Messina WA, Koch FH, Gomez D, Hulcr J (2020) A bioeconomic model for estimating potential economic damages from a hypothetical Asian beetle introduced via future trade with Cuba. J Bioeconomics 22(1):33-58. https://doi.org/10.1007/ s10818-019-09289-x 
Adusumilli N, Wang H, Dodla S, Deliberto M (2020) Estimating risk premiums for adoption no-till and cover crops management practices in soybean production system using stochastic efficiency approach. Agric Syst 178:102477. https://doi.org/10.1016/j.agsy.2019.102744

Albaugh TJ, Fox TR, Cook RL, Raymond JE, Rubilar RA, Campoe OC (2019) Forest fertilizer applications in the southeastern United States from 1969 to 2016. For Sci 65(3):355-362. https://doi.org/ 10.1093/forsci/fxy058

Allen CB, Will RE, Jacobson MA (2005) Production efficiency and radiation use efficiency of four tree species receiving irrigation and fertilization. For Sci 51(6):556-569. https://doi.org/10.1093/fores tscience/51.6.556

Anderson JR, Dillon JL (1992) Risk analysis in dryland farming systems. Italy, Rome

Anderson JR, Hardaker JB (2003) Risk aversion in economic decision making: pragmatic guides for consistent choice by natural resource managers. In: Wesseler J, Weikard HP, Weaver RD (eds) Risk and uncertainty in environmental and natural resource economics. Edward Elgar, Cheltenham, pp $171-187$

Anderson JR, Dillon JL, Hardaker JB (1977) Agricultural decision analysis. Iowa State University Press, Ames

Andersson M (2012) Assessing nonindustrial private forest owners' attitudes to risk: do owner and property characteristics matter? J For Econ 18(1):3-13. https://doi.org/10.1016/j.jfe.2011.05.001

Andersson M, Gong P (2010) Risk preferences, risk perceptions and timber harvest decisions-an empirical study of nonindustrial private forest owners in Northern Sweden. For Policy Econ 12(5):330339. https://doi.org/10.1016/j.forpol.2010.02.002

Armstrong GW (2004) Sustainability of timber supply considering the risk of wildfire. For Sci 50(5):626639. https://doi.org/10.1093/forestscience/50.5.626

Austin KG, Baker JS, Sohngen BL, Wade CM, Daigneault A, Ohrel SB, Ragnauth S, Bean A (2020) The economic costs of planting, preserving, and managing the world's forests to mitigate climate change. Nat Commun 11(1):1-9

Babcock BA, Choi EK, Feinerman E (1993) Risk and probability premiums for CARA utility functions. J Agric Resour Econ 18(1):17-24

Blazier MA, Dunn MA (2008) Stock type, subsoiling, and density impact productivity and land value of a droughty site. South J Appl For 32(4):154-162. https://doi.org/10.1093/sjaf/32.4.154

Blazier MA, Scott DA, Coleman R (2015) Mid-rotation silviculture timing influences nitrogen mineralization of loblolly pine plantations in the Mid-South USA. For 6:1061-1082. https://doi.org/10.3390/ f6041061

Blazier MA, Scott DA (2006) Nitrogen distribution within the soil-plant-microbial system in response to pre-thinning fertilization treatments in Louisiana. P. 129-134. In: Connor, K.F. (ed.). Proceedings of the 13th biennial southern silvicultural research conference. Gen. Tech. Rep. SRS-92. Asheville, NC: US Department of agriculture, forest service, Southern Research Station. P. 640

Brazee RJ, Dwivedi P (2015) Optimal forest rotation with multiple product classes. For Sci 61(3):458465. https://doi.org/10.5849/forsci.13-207

Brazee RJ, Mendelsohn R (1988) Timber harvesting with fluctuating prices. For Sci 34(2):359-372

Brunette M, Foncel J, Kéré EN (2017) Attitude towards risk and production decision: an empirical analysis on French private forest owners. Environ Model Assess 22:563-576. https://doi.org/10.1007/ s10666-017-9570-6

Bullock BP, Burkhart HE (2003) Equations for predicting green weight of loblolly pine trees in the South. South J Appl For 27(3):153-159. https://doi.org/10.1093/sjaf/27.3.153

Buongiorno J, Zhou M, Johnston C (2017) Risk aversion and risk seeking in multicriteria forest management: a Markov decision process approach. Can J for Res 47(6):800-807. https://doi.org/10.1139/ cjfr-2016-0502

Butler BJ, Wear DN (2013). Forest ownership dynamics of southern forests. In: Wear DN, Greis John G (eds) The southern forest futures project: technical report. Gen. Tech. Rep. SRS-GTR-178. Asheville, NC, pp. 103-121, 178, 103-121

Butler BJ, Butler SM, Caputo J, Dias J, Robillard A, Sass EM (2020) Family forest ownerships of the United States, 2018: results from the USDA forest service, national woodland owner survey. Gen. Tech. Rep. NRS-199.Madison, WI: U.S. Department of agriculture, forest service, Northern research station. p. 52[plus 4 appendixes]. https://doi.org/10.2737/NRS-GTR-199

Caulfield JP (1988) A stochastic efficiency approach for determining the economic rotation of a forest stand. For Sci 34(2):441-457. https://doi.org/10.1093/forestscience/34.2.441 
Couture S, Cros MJ, Sabbadin R (2016) Risk aversion and optimal management of an uneven-aged forest under risk of windthrow: a Markov decision process approach. J For Econ 25:94-114. https://doi. org/10.1016/j.jfe.2016.08.002

Cowan T, Johnson R (2008) Conservation provisions of the 2008 farm bill. CRS Report. RL34557

Coyle DR, Aubrey DP, Coleman MD (2016) Growth responses of narrow or broad site adapted tree species to a range of resource availability treatments after a full harvest rotation. For Ecol Manag 362:107-119. https://doi.org/10.1016/j.foreco.2015.11.047

Ferreira GW, Rau BM, Aubrey DP (2020) Herbicide, fertilization, and planting density effects on intensively managed loblolly pine early stand development. For Ecol Manag 472:118206. https://oi.org/ 10.1016/j.foreco.2020.118206

Fox TR, Allen HL, Albaugh TJ, Rubilar R, Carlson CA (2007a) Tree nutrition and forest fertilization of pine plantations in the southern United States. South J Appl for 31(1):5-11. https://doi.org/10.1093/ sjaf/31.1.5

Fox TR, Jokela EJ, Allen HL (2007b) The development of pine plantation silviculture in the southern United States. J For 105(7):337-347. https://doi.org/10.1093/jof/105.7.337

Gong P (1998) Risk preferences and adaptive harvest policies for even-aged stand management. For Sci 44(4):496-506. https://doi.org/10.1093/forestscience/44.4.496

Gong P, Löfgren KG (2003) Risk-aversion and the short-run supply of timber. For Sci 49(5):647-656

Hanewinkel M, Hummel S, Albrecht A (2011) Assessing natural hazards in forestry for risk management: a review. Eur J for Res 130(3):329-351. https://doi.org/10.1007/s10342-010-0392-1

Hardaker JB, Richardson JW, Lien G, Schumann KD (2004) Stochastic efficiency analysis with risk aversion bounds: a simplified approach. Aust J Agric Resour Econ 48(2):253-270. https://doi.org/10. 1111/j.1467-8489.2004.00239.x

Henderson J, Boby L, Hubbard W (2015) The economic importance of forestry in the south2014. Southern regional extension forestry technical bulletin SREF-FE-002 p.2

Hugget R, Wear DN, Li R, Coulston J, Liu S (2013) Forecasts of forest conditions. In: Wear DN, Greis J (eds) The southern forest futures project: technical report. US Department of Agriculture Forest Service: Asheville, NC, USA. pp. 73-101

Jacobsen JB, Helles F (2006) Adaptive and nonadaptive harvesting in uneven-aged beech forest with stochastic prices. For Policy Econ 8(3):223-238. https://doi.org/10.1016/j.forpol.2004.06.004

Jokela EJ, Dougherty PM, Martin TA (2004) Production dynamics of intensively managed loblolly pine stands in the southern United States: a synthesis of seven long-term experiments. For Ecol Manag 192(1):117-130. https://doi.org/10.1016/j.foreco.2004.01.007

Jokela EJ, Martin TA, Vogel JG (2010) Twenty-five years of intensive forest management with southern pines: important lessons learned. J for 108(7):338-347. https://doi.org/10.1093/jof/108.7.338

Kant S, Alavalapati J (eds) (2014) Handbook of forest resource economics. Routledge, London

Keeney RL, Raiffa H (1976) Decisions with multiple objectives: preferences and value tradeoffs. Wiley Publishers, New York

Khanal PN, Grebner DL, Straka TJ, Adams DC (2019) Obstacles to participation in carbon sequestration for nonindustrial private forest landowners in the southern United States: a diffusion of innovations perspective. For Policy Econ 100:95-101. https://doi.org/10.1016/j.forpol.2018.11.007

Kline KL, Coleman MD (2010) Woody energy crops in the southeastern United States: two centuries of practitioner experience. Biomass Bioenerg 34:1655-1666. https://doi.org/10.1016/j.biombioe.2010. 05.005

Leskinen P, Kangas J (2001) Modelling future timber price development by using expert judgments and time series analysis. Silva Fennica 35(1):93-102

Lien G, Størdal S, Hardaker JB, Asheim LJ (2007) Risk aversion and optimal forest replanting: a stochastic efficiency study. Eur J Oper Res 181(3):1584-1592. https://doi.org/10.1016/j.ejor.2005.11.055

Lintunen J (2011) Timber supply from an age-class structured forest under rational expectations. http:// www.feem-web.it/ess/ess11/files/selected_papers/lintunen.pdf. Accessed 28 October 2021

Lönnstedt L, Svensson J (2000) Nonindustrial private forest owners' risk preferences. Scand J For Res 15(6):651-660. https://doi.org/10.1080/02827580050216905

Maggard A, Barlow B (2019) Costs and trends for Southern forestry practices 2018. For-2073, Alabama cooperative extension service. https://www.aces.edu/blog/.../costs-trends-of-southern-forestry-pract ices-2018 I

Martin TA, Jokela EJ (2004) Stand development and production dynamics of loblolly pine under a range of cultural treatments in north-central Florida USA. For Ecol Manag 192(1):39-58. https://doi.org/ 10.1016/j.foreco.2004.01.004 
Oswalt SN, Smith WB, Miles PD, Pugh SA (2019) Forest resources of the United States, 2017: a technical document supporting the forest service 2020 RPA assessment. Gen. Tech. Rep. WO-97. Washington, DC: US department of agriculture, forest service, Washington Office. p. 97. https://doi.org/ 10.2737/WO-GTR-97

Pendell DL, Williams JR, Boyles SB, Rice CW, Nelson RG (2007) Soil carbon sequestration strategies with alternative tillage and nitrogen sources under risk. Rev Agric Econ 29:247-268

Richardson J, Schumann K, Feldman P (2006) Simulation and econometrics to analyze risk, Simetar. Inc. 2006 user manual. College station, TX

Schultz RP (1997) The ecology and culture of loblolly pine (Pinus taeda L.). Agriculture handbook \#713, USDA forest service, Washington, DC, p. 493

Schumann KD, Richardson JW, Lien GD, Hardaker JB (2004) Stochastic efficiency analysis using multiple utility functions. The American agricultural economics association annual meeting, Denver, Colorado. No. 377-2016-20749.

Susaeta A, Gong P (2019) Optimal harvest strategy for even-aged stands with price uncertainty and risk of natural disturbances. Nat Resour Model 32(3):12211. https://doi.org/10.1111/nrm.12211

Susaeta A, Carter DR, Chang SJ, Adams DC (2016) A generalized reed model with application to wildfire risk in even-aged southern United States pine plantations. For Policy Econ 67:60-69. https://doi. org/10.1016/j.forpol.2016.03.009

Tanger S (2019) Louisiana timber market report fourth quarter (Oct-Dec) 2018. LSU AgCenter. Staff Report 2019-07. https://lsuagcenter.com/profiles/stanger/articles/page1548350319421

Taylor R, Fortson J (1992) Optimum plantation planting density and rotation age based on financial risk and return. For Sci 37(3):886-902

US Department of Agricultural Natural Resource Conservation Service (USDA NRCS) (2020) Web soil survey. https://websoilsurvey.sc.egov.usda.gov/App/HomePage.htm

Uusivuori J (2002) Nonconstant risk attitudes and timber harvesting. For Sci 48(3):459-470

Wang H, Adusumilli N, Gentry D, Fultz L (2020) Economic and stochastic efficiency analysis of alternative cover crop systems in Louisiana. Exp Agric 56(5):651-661

Williams JD, Gollany HT, Siemens MC, Wuest SB, Long DS (2009) Comparison of runoff, soil erosion, and winter wheat yields from no-till and inversion tillage production systems in northeastern Oregon. J Soil Water Conserv 64:43-52. https://doi.org/10.2489/jswc.64.1.43

Williams JR, Pachta MJ, Roozeboom KL, Llewelyn RV, Claassen MM, Bergtold JS (2012) Risk analysis of tillage and crop rotation alternatives with winter wheat. J Agric Appl Econ 44(4):561-576

Yousefpour R, Jacobsen JB, Thorsen BJ, Meilby H, Hanewinkel M, Oehler K (2012) A review of decision-making approaches to handle uncertainty and risk in adaptive forest management under climate change. Ann For Sci 69(1):1-15. https://doi.org/10.1007/s13595-011-0153-4

Zhang F, Chang SJ (2018) Measuring the impact of risk preference on land valuation: evidence from forest management. Land Econ 94(3):425-436. https://doi.org/10.3368/le.94.3.425

Publisher's Note Springer Nature remains neutral with regard to jurisdictional claims in published maps and institutional affiliations. 


\section{Authors and Affiliations}

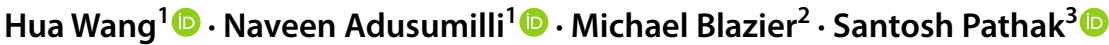

Hua Wang

Hwang23@1su.edu

Michael Blazier

mblazier@agcenter.lsu.edu

Santosh Pathak

spath11@1su.edu

1 Department of Agricultural Economics and Agribusiness, Louisiana State University Agricultural Center, Baton Rouge, LA 70803, USA

2 Hill Farm Research Station, School of Renewable Natural Resources, Louisiana State University, 11959 Hwy. 9, Homer, LA 71040, USA

3 Department of Agricultural Economics and Agribusiness, Louisiana State University, Baton Rouge, LA 70803, USA 